\title{
HISTORICAL FOLKLORE PROSE OF THE RUSSIAN METALLURGICAL TRADITIONS OF THE KOMI REPUBLIC
}

\author{
Yulia Krasheninnikova \\ Senior Research Fellow \\ Department of Folklore, Institute of Language, Literature, and History \\ Komi Science Centre, Russian Academy of Sciences, Russia \\ Email: krasheninnikova@rambler.ru
}

\begin{abstract}
The article introduces folklore materials collected in the twenty-first century from the Russian population of the mining villages in the Komi Republic, founded when iron mining started in the area in the middle of the eighteenth century. The folklore traditions originated from the Russian settlers coming from the northern, north-eastern, and central provinces of the European part of the Russian Empire. The author studies the stories of oral historical prose, reflecting the values of the settlers, events in the course of settling and reclaiming the territory, the beginning and development of pig iron and iron production, local dynasties, and information about actual historical prototypes. She also considers the procedure of forming a folklore repertory in a certain local tradition. By using historical sources and mass media publications and comparing them to folklore materials, the author concludes that in the twentieth century, the collective historical memory was 'designed', among others, by resources, the mass media, and book culture, and that local intellectuals were directly involved in the process.
\end{abstract}

Keywords: formation of the folklore repertoire, Komi Republic, oral historical prose, Russian folklore traditions

\section{SEVERAL FEATURES OF THE FORMATION AND STUDYING OF LOCAL TRADITIONS}

This work is dedicated to the Russian folklore traditions of the Nyuvchim (Syktyvdinsky District), Kazhym, and Nyuchpas (Koygorodsky District) factory settlements, the emergence of which on the territory of the Komi Republic was related to the opening of the iron-ore businesses in 1756-1761. The initiative of the building of the Kazhym, Nyuchpas, and Nyuvchim private metallurgical plants at the Sysola River and its tributaries is attributed to the merchants Andrey Panov, Andrey Plotnikov (Nyuvchim plant), Ivan Kurochkin, 
and Aleksandr Yurinsky (Kazhym and Nyuchpas plants), who, after having discovered deposits of bog iron ore at the Sysola River and researched the raw-material base, turned to the Collegium of Mining, which managed the development of the factory sector in Russia at the time, with a request to allow them to build the plants. In 1761, the plant in Nyuvchim was commissioned, and the plants in Kazhym and Nyuchpas started their operation in 1758 and 1757 respectively (Politov 2005: 91-93). ${ }^{1}$

Initially the main population (its qualified part) within the industry was made up by state peasants from the Vyatka and Veliky Ustiug provinces, who had been trained to work at the plant; fugitive peasants, who were hiding from compulsory military service and were paying duties were also hired (Politov 2005: 109, 111). The facts of state peasants from Slobodskoy and Yaransky uyezds of Vyatka Governorate, from the village of Seregovo (Zherebtsov 1962: 126), the recruitment at the beginning of the twentieth century of the labour force from Moscow, the Urals, and other governorates were recorded (Surina 1973: 69). From the archival documents of the turn of the nineteenth century, in particular, we learn about the intention of the owner of the Nyuvchim plant, Arkhip Gribanov, to buy 118 peasants (65 males and 53 females) from Vetluzhsky Uyezd of Kostroma Governorate and 118 peasants (56 males and 62 females) from Kadnikovsky Uyezd of Vologda Governorate (Politov 2005: 112).

As a matter of fact, the reference point of the formation of folklore traditions of the settlements of Nyuvchim, Kazhym, and Nyuchpas can be regarded to be the middle of the eighteenth century, after the plants were commissioned. In connection with the predominance of the population coming from the northern Russian and central governorates of the European part of Russia, a folklore culture based on the traditions of the places the plant workers were coming from was formed. ${ }^{2}$ The distinctive character of settlements (plant settlements with the 'town-forming' company), the functioning of the plants until the middle (the village of Kazhym) and the end of the twentieth century (the village of Nyuvchim), the inhomogeneous structure of the Russian population, and close contacts with the local Komi and settlers banished from different places in Russia - all of these factors as well as many others exerted their influence on the formation of the local folklore culture and, to a certain extent, determined the structure of folklore traditions.

In the process of its formation and development, migratory culture was experiencing non-unilinear and ununiform exposure. Firstly, the interaction of the Russian migratory and the indigenous Komi cultures should be mentioned. Secondly, 'folklore interrelations' inside the new settlers' traditions, apparently, were unequal too, since traditions were formed by the Russian population from different areas of Russia, and, correspondingly, the migrants were introducing 
their own perceptions of the lifestyle and spiritual culture into the local tradition. However, the preservation and predominance of one or another cultural phenomenon and the linguistic peculiarities of native territories were influenced by the quality and quantity of the migrant population, their level of responsiveness and permeability, and the aggressiveness of both the local and folklore environments and the traditions introduced by migrants. In addition to that, in the first half of the twentieth century, the 'blurring' of traditions and the adjustment of the cultural constituents were implicitly affected by the multinational component pertaining to the settlers banished here. In particular, modern field research data contain considerable evidence confirming the fact that from the 1930s to the beginning of the 1950s, the villages of Nyuvchim, Kazhym, and other small places located near the settlements were inhabited by deported Jews, Poles, Ukrainians, Belarusians, Germans, and other nationalities.

Folklore traditions in the settlements of Nyuvchim, Kazhym, and Nyuchpas have not been an object under special study so far. ${ }^{3}$ The first folklore field studies were undertaken by the ethnic musician Prometheus Chistalyov, who mainly sought to record data about song culture. In the period of 1957-1961, he recorded quite a large corpus of song texts of different genres from local bands and talented individual performers. Work with Chistalyov's field diaries and sound recordings ${ }^{4}$ has enabled us to restore the repertoire lists. ${ }^{5}$ He recorded different genres of non-ritual lyric songs, playing songs, children's folklore, ritual lyric, lamentations, etc. ${ }^{6}$ In the $1960 \mathrm{~s}$, there was no clear setting for recording prosaic genres or any other information pertaining to the spiritual culture of the local population. In this respect, there is a gap in the research of the designated folklore traditions, which began to be filled by modern folklorists only in the first decade of the twenty-first century. Methodical work by means of 'total survey' was done by folklorists of the Institute of Language, Literature, and History in the village of Nyuvchim in 2008, 2011, and 2015, in the village of Kazhym in 2010, 2013, and 2017, and in the village of Nyuchpas in 2011, 2013, and 2017.

\section{RESEARCH METHODS}

Pertaining to the observations related to the formation of the local folklore repertoire, the observations made by Nikita Tolstoy about the forms, means, and 'consequences' of the process of interaction between the cultures that are so different in ethnic terms are of immediate interest. In particular, the point he made about the permeability/non-permeability of different phenomena of folk culture and the inhomogeneous nature of the Slavic folklore genres with respect 
to their susceptibility to foreign folklore and non-folklore fund are particularly significant (see Tolstoy 1995: 53). The researcher lists anecdotes, fairy tales, legends, spiritual verse, and minor folklore genres among the 'susceptible' forms that are 'open' for foreign folklore and non-folklore funds; ritual calendar and family poetry as well as epic poetry are mentioned among 'unsusceptible' and 'closed' genres, the fragments of which can be borrowed 'only with the ritual and the language' (Tolstoy 1995: 53). Andrey Vlasov was more exact when, while talking about the process of formation of the Russian local traditions in the Komi Republic, he pointed out that "the recognition of its own "migratory status", as a matter of fact, its isolation from the surrounding local (even nonethnic) population facilitates the reinforcement in the historical memory of migrants of the traditional forms of folklore culture as the means for reinforcing their "otherness" among indigenous inhabitants, while it also promotes the "birth" of their own world, i.e., the homeland, for further generations' (Vlasov 2007: 13). Vlasov highlights the importance of differentiating between the 'inherited' (which includes the elements of mythological worldview, traditional song forms, ritual folklore, fairy-tale prose, etc.) and 'newly acquired' (historical or legendary prose, the details of ritual complexes, new song growth, toponymy) folklore fund (Vlasov 2007: 13-14).

Taking those assumptions into account, let us make some observations concerning the acquired folklore, which was formed in the new territory, and the hereditary folklore, brought by migrants and containing references to their homeland: historical prose related to the iron-ore industry and the set of Christmas rituals of the Russian population in the settlements of plant workers in the republic (see Krasheninnikova \& Nizovtseva 2019).

It bears repeating that I have had a chance to study those traditions at quite a late stage of their existence. In this respect, a few details should be pointed out. Firstly, the lack of earlier records allows us to describe the synchronous cross-section of the tradition. Taking the age of informants into consideration, we can discuss the state of the tradition in the first third of the twentieth century. Secondly, there was an influx of banished settlers and recruited population in the twentieth century, which resulted in changes in the structure of the basic oldtimer population. Finally, the stability of the oral historical memory of the local population is provided for by local enthusiasts and lore specialists; as a matter of fact, the 'designing' of collective historical memory in the twentieth century took place through the active participation of the mass media and book culture and the staff of local museums, schools, and libraries. The familiarization with the materials that were published in the local press (newspapers, magazines) and their comparison with the records made during field studies enable us to say that some of the plots that were widespread in the oral tradition had been introduced into it, in particular, owing to the range of sources listed above. ${ }^{7}$ 


\section{SOURCES AND MECHANISMS OF FORMATION OF THE REPERTOIRE OF ORAL HISTORICAL PROSE}

The stock of the oral prose within the traditions listed above is much wider. However, a major part of the recorded field data is related to the iron-foundry and metallurgical industries. In this prose, the worldview attitudes of the migrants were reflected as well as the events related to the reclaiming and settling of the territory, the birth and development of production, information about local dynasties, and references to authentic historical persons. The most popular are the motifs about the migration of peasants from the Russian governorates; the motif of establishing ore businesses as a result of selling/ buying the deposits (land) or people to cover gambling debts; the motif of the reclamation and development of space, turning uninhabited foreign space into someone's own and habitable; and the motif about connections between the Urals and Saint Petersburg. Time coordinates are actualized; for example, the time of establishment of ore businesses related to the rule of the empresses Elizaveta Petrovna (Elizabeth) and Catherine the Great, as well as geographical coordinates (migrants come from inhabited localities in Vologda, Vyatka, Arkhangelsk, and Perm governorates, and Siberia). Some of the motifs and images are local and are only typical of certain settlements; for example, the motif of the special part played by industrialist Demidov ${ }^{8}$ is typical of the village of Kazhym, while in the Nyuvchim tradition, texts describing the elaborate image of Emperor Nicholas II and the motif of the connection between the tsar's family and the Nyuvchim plant are recorded.

In stories about ancestors, etiological motifs (the origins of family lines, the specification of topographic and historical coordinates of the native land of the ancestors, etc. ${ }^{9}$ ) are extremely laconic, and the image of the ancestral home of the first settlers does not have any specific outlines. In texts recorded from different informants, the motif of the migration of peasants from the Russian governorates, i.e., Vologda, Vyatka, Arkhangelsk, and Perm governorates, and others, is actualized, but it is realized to a very small degree (sometimes by a single mentioning), for example:

The industrialist bought peasants and moved them here. They settled down here, mixed with the locals, felt at home among them, so to say. They were brought here from the Kirov and Vyatka Oblasts... ${ }^{10}$

Bonded peasants from Arkhangelsk and Vologda, when the settlement was established, bonded peasants were sold. They were brought here from Vologda, Arkhangelsk, and Kirov, and they settled down here, and their customs and traditions also remained. ${ }^{11}$ 


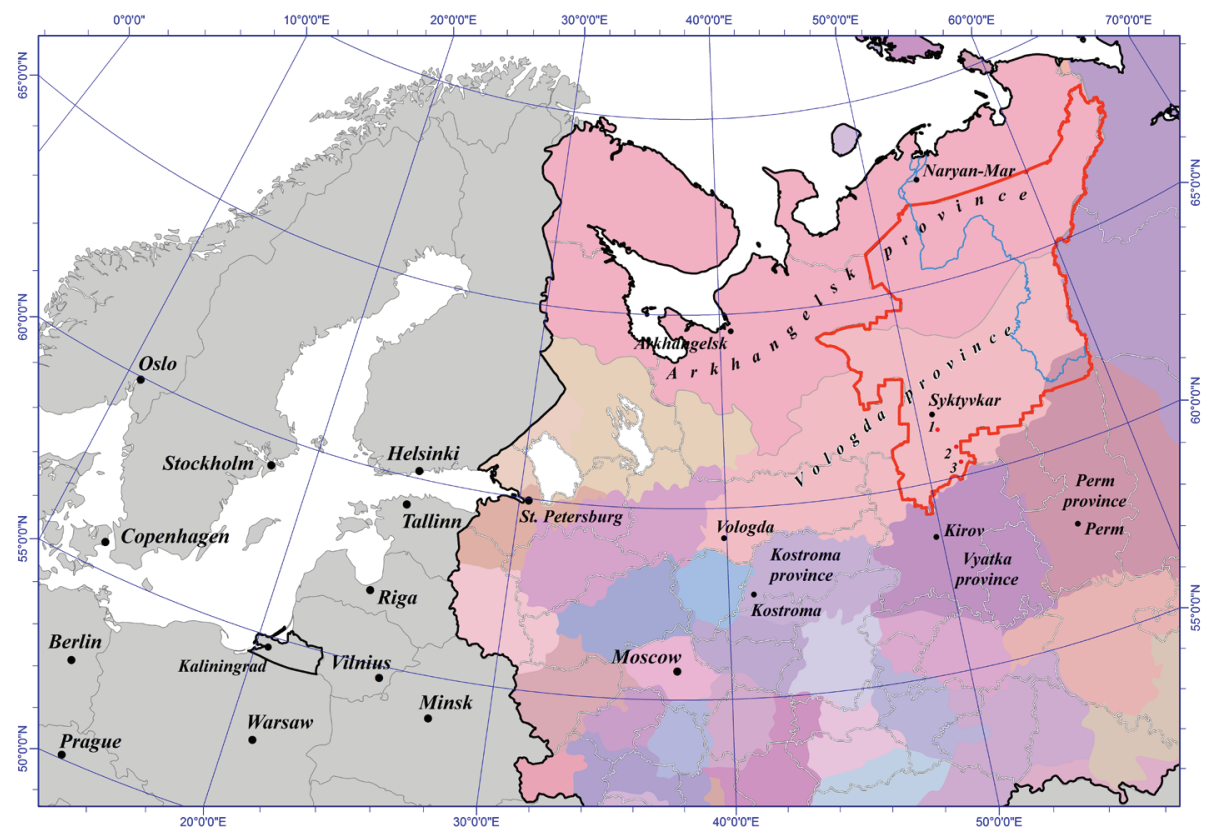

Figure 1. The colored areas of the map illustrate the administrative divisions in Russia in 1914. The black line marks the contemporary borders of Russia; the red line marks the contemporary borders of the Komi Republic. The location of iron industry settlements in the Komi Republic: 1 - Nyuvchim (Syktyvdinsky District), $\mathbf{2}$ - Kazhym, and $\mathbf{3}$ - Nyuchpas (Koygorodsky District). The map is contributed by Vladimir Elsakov and Leonid Rybin (Institute of Biology of Komi Science Centre of the Ural Branch of the Russian Academy of Sciences).

Some texts contain hereditary patronyms, which are represented by informants as an indication of their native homeland:

My mother's surname is Soboleva, they brought the Sobolevs and the Savelyeus from Vologda Governorate... ${ }^{12}$

Where were our grandfathers brought from? They were brought from Vologda Governorate, from there. ... Somewhere in Perm Governorate ... there is the entire village of the Semyachkovs [last name - Y.K.], and they were sent here from over there. She [the local lore specialist - Y.K.] read somewhere in the archive that the two Semyachkov brothers came here in $1816 . .{ }^{13}$

There are mainly Siberians here. Surnames like Usatov, Kuvardin, Kurdyukov. ${ }^{14}$ 


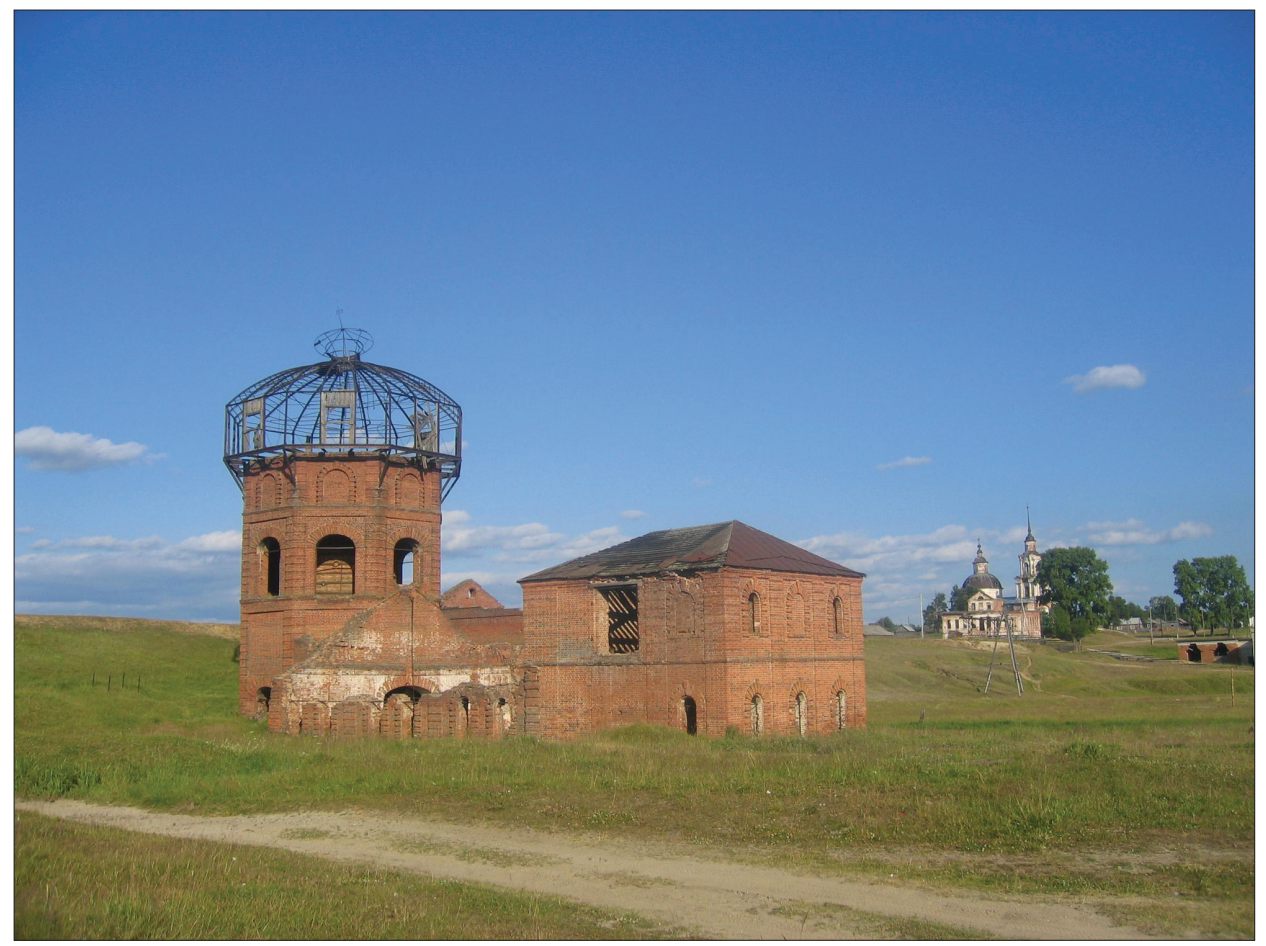

Figure 2. Building of an iron foundry; in the background the Church of St. Dimitry of Rostov. Settlement of Kazhym, Koygorodsky District. Photograph by Yulia Krasheninnikova 2010.

In terms of their meaning, some folklore records refer us to published material about the history of the local industries, which apparently was used during school, museum, and production events and appeared in newspaper articles.

The memory about the homeland of the first settlers was embedded in a number of patrimonial nicknames: the Vaganovs - ancestors from the Vaga River in Arkhangelsk Oblast; the Solins - from the town of Solvychegodsk; the newcomers from Kirov Oblast to the village of Kazhym were referred to as Kirov bast shoes, because they were wearing bast shoes. ${ }^{15}$

In oral stories, time coordinates are recorded. For example, the time period of the establishment of the industry is aligned with the rule of the empresses Elizaveta Petrovna and Catherine the Great. According to one of the versions, the discovery of bog ore deposits near the village Nyuvchim took place during the rule of Elizabeth (1741-1762). 
During the rule of Elizabeth II, one industrialist found ore in bogs, rusty stones, iron. And he decided to build a plant here and smelt ore. The first smelting took place in 1742. There were thick woods over here. He brought bonded peasants from Kirov Oblast and other oblasts, he bought [them]. And then they built houses here, and they built a wooden plant and started smelting ore... ${ }^{16}$

The version about Catherine the Great (who ruled from 1762 until 1796) was more widespread. Catherine the Great sent people from Siberia to Kazhym, and among the first settlers here were Siberians with the surname of Kuvardin; ${ }^{17}$ she came to Kazhym herself to supervise the organization of the work at the plant, and sent plant workers here who started to develop the industry; ${ }^{18}$ she gambled away the land, on which ore was found later on; ${ }^{19}$ she sent bonded peasants from the Volga region to develop the industry.

I was always asking about why we are not the Komi, even though we were born in the Komi Republic. And my grandfather told me that... Catherine the Great would expel bonded peasants from the Volga region and send them to develop the ore industry, there're ironworks here. ... And our ancestors on my mother's side, on her parents' side, are from the Volga region... ${ }^{20}$

All of the events related to the development of the plant and deportation of people are referred by some of the informants only to the rule of Catherine the Great.

- Peasants were brought [P. P.]. Oh, it happened during Catherine's rule! It's a long story [D. P.]. People were brought here from the Volga River... [P. P.]. They were bought and sold many times, the old ones. The Tvorozhnikovs, Kolesovs, Smyachkovs, and Anisimovs. All of these surnames come from different governorates.

- How did they get here?

- Perhaps they were brought here to work. I think Kosolapin as well. The plant was built during Catherine's rule, it was written somewhere, I read it somewhere; all of these workers were brought from different governorates. ${ }^{21}$

The motif of the establishment of the ore industry as a result of the sale/purchase of the deposits (land) or people to cover a gambling debt is also very consistent. In different texts, the land and peasants were gambled away 'from one landowner to another', by merchants, or Catherine the Great; the settlement and the ancestors of its modern inhabitants are referred to as 'gambled away', 'deported from Russia on account of her debt', 'purchased and sold', 'slaves that 
were gambled away', and 'bonded peasants'. In numerous texts and laconic evidence the idea of the forced migration of peasants is actualized: firstly, by calling the migrants as 'slaves' or 'peasants'22; secondly, the process itself is regarded as a negative one to be disapproved of, which is represented by the verb to send away 'to make someone leave, to move out of the borders of something, to exile (usually by the decision of an administrative or judicative authority)' (Yefremova 2000), and also by more neutral verbs, such as to bring 'to deliver somewhere by carriage' (Ushakov 1939: column 768), to send 'to dispatch, to refer to, to send on an errand', which also take on a negative connotation in the context of talking about the forced nature of migration.

- Catherine gambled away the settlement, she gambled it away. They sent the entire settlement here, to Kazhym.

- There was nothing here?

- There was nothing here.

- Did she gamble away the land?

- No, people...

- Was it a gambling debt?

- I don't know, I don't know anything about a gambling debt, but I heard that our settlement had been gambled away, we are the exiled ones. Our ancestors were exiled from Russia. And there were only Russian people here. In Koigorodok, there were the Komi. And we had all Russians here. ... We are the exiled ones. Our ancestors, not my parents, but their parents, they are buried here, too, they were gambled away, two hundred years ago, I think. Our whole settlement was gambled away. ${ }^{23}$

- Well, when they were gambled away, the Demidovs were brought here, our grandfathers and great-grandfathers. And they just settled down here. - What do you mean by being gambled away? Who gambled them away? - The director. They were somewhere near Moscow, our great-grandfathers. And some merchant gambled them away, it was a gambling debt, to the Demidovs. And the Demidovs... brought them here to Nyuvchim... ${ }^{24}$

While describing the staff of the plants at the Sysola River, historians point out that state peasants of voluntary recruitment, who had been trained to work at the plant, were working at the plants as craftspeople, and peasants were only bought in small numbers at the end of the eighteenth to the beginning of the nineteenth centuries (Politov 2005: 109, 112). In addition to that, in scientific and popular scientific publications of the twentieth century the idea about serious distress and hardships experienced by plant workers ('bonded labour', 
'enslavement') is emphasized, and the researchers talk about legal and illegal measures taken by plant owners in order to keep the workers at the plant and turn them from 'people with personal freedom into plant slaves' (Politov 2005: 110), about the 'half-villeinage system' of supply of the industry with labour force in its essence (Surina 1973: 25), and many others. It is possible that these statements, alongside other factors, had an impact on the emergence of texts with the motifs described above in the local prose.

One of the first mentions about peasants that assumedly had been gambled away was found in an essay by Alexander Anisimov (1924). This local lore specialist cites 'a true story', according to which the peasants from Kadnikovsky Uyezd, leaving for 'the unknown land', 'into a thick wood inhabited by wild animals and the wild Zyrians', 'collected their stuff and went to the new landlord - the plant owner [apparently, it is about Gribanov - Y.K.]', because 'they heard that the landlord had gambled them away to Gribanov' (Anisimov 1924: 61-62). The motif of selling something (land, people) on account of a gambling debt, which is very widespread in the folklore and literature tradition ${ }^{25}$ as well as precedent-setting facts that took place in real life, gave an impetus to the generation of the corpus of folklore texts with the motifs of playing cards and gambling debts. It also appears in the reminiscences that describe the everyday life of the local people of Nyuvchim. Informants specify that playing cards was one of the best-loved pastimes of plant owners:

Everyone was playing here. Everyone was playing cards here, they gambled away cows and everything else. An old man lived here, Nikanor's father, and he played cards until his cow was taken away from him. Yes, many people were gambling away cows. ${ }^{26}$

Quite often the motif of being connected to Saint Petersburg is realized in texts, which was furthered by the information that often comes up in publications about private plants fulfilling state orders and participating in the industrial life of the country. For example, Butlerov, the last pre-revolutionary owner of the plant, lived in Saint Petersburg: '... the last plant owner was Butlerov, either before or immediately after the revolution. It does not say that anywhere, but he had an oval-shaped stamp saying "Plant Owner Butlerov". ... Butlerov lived in Saint Petersburg'. ${ }^{27}$ The Nyuvchim plant is referred to as the 'Treasury', which is indicative of the fact that it was recognized as a state company: 'It used to be called the Treasury, not the plant. People were working at the Treasury. [They said]: "We are working at the Treasury...". ${ }^{28}$ There is reliable information proving that cast iron and iron produced at the plants in Nyuvchim and Kazhym were used when casting the gates and the roofs of the Winter Palace in Saint 
Petersburg. It is curious that the informants from Kazhym also mention other buildings in Saint Petersburg ('the roof of some church is covered with the iron made here'29, 'it was even taken to Saint Petersburg and used to roof the building in tsarist times... ${ }^{30}$ ) and in Moscow. The active pedalling of this topic by the inhabitants of Kazhym and Nyuvchim, their 'competitiveness' for the right to be involved in one of the historical and cultural 'centres' of Russia is one of the most significant facts of the local social 'biography'. Informants speaking about a large silver medal that in 1896 was awarded at the All-Russian Product Fair in Nizhny Novgorod for 'office casting' made at Nyuvchim ${ }^{31}$ (in folk local terms: 'coloured', 'shaped' casting) misinform collectors unintentionally, saying that the medal was also awarded for the production made in Kazhym:

The tsar's palace in Saint Petersburg was covered with Kazhym iron. ... Even in 1896 at the All-Russian Product Fair in Nizhny Novgorod Kazhym iron, and the products made from it, and from cast iron, were awarded with a small golden medal. ${ }^{32}$

Finally, two more motifs are distinguished in the local prose, which are spread locally and related to the description of the life of some people that were famous in Russian history. In the folklore prose of the village of Kazhym, a regular motif concerns the special role played by the industrialist Demidov in the organization and development of the local ore industry. ${ }^{33}$ The belonging of the local ore industry to the Urals and a group of the Ural plants (quite often the local plants are referred to as 'Demidov's plants') is highlighted in texts, and Demidov has the attributes of 'being in charge of iron foundries', 'the main leader', 'the only owner', who was sending people from the Urals and Siberia to work at the local plants. The local population associates the establishment of the plant in the village of Kazhym with Demidov's initiative, emphasizing that the local blast furnace was built by the type of the Ural ones ${ }^{34}$, or pointing at the equivalence between the organization of the Ural and Kazhym production ('We had similar dams, and the plants were similar. But this Demidov also had plants [about the plants in Nyuvchim and Nyuchpas - Y.K.]. ${ }^{35}$ Either by Demidov himself or by his order, exploration surveys were done in order to organize production.

Overall, these were Demidov's plants. Demidov was obviously sending people here to found iron ... Well, yes, Demidov was their main boss. He also had some assistants, they were managing the plant on the spot. I think the old people say that Demidov never even came here, not even once. ${ }^{36}$

And, finally, in one of the texts Demidov is referred to an inhabitant of Kazhym, a native of the village, a member of the local population, i.e., 'their own': 
- Have you heard the surname of Demidov?

- Demidov, yes, of course, he was local, from Kazhym, I think he was the manager ..., my mother said that to me once.

- Was he the manager? Was it his plant?

- Yes, it was his plant, you're right. ${ }^{37}$

Why does the image of Demidov appear in the local prose? According to the historical data, none of the Demidovs visited the local plants, but the name of Demidov is related to the beginning, development, and blossoming of the mining and metallurgical industries in Russian history. Apparently, the longlasting associative link of 'mining - iron foundry - Ural - Demidov' 'went off' at the level of folklore consciousness and gave an impetus to the emergence of the image of Demidov. By the way, this association has been implicitly used in local publications in the twentieth and twenty-first centuries, which tell about the history of the emergence of the industry in question. ${ }^{38}$ In local oral prose, Demidov has neutral characteristics, while in a number of texts he is also assigned with positive properties: to some extent he appears as a demiurge, the discoverer of the industry, who had the creative powers, skills, and knowledge required for the establishment and development of the plants. ${ }^{39}$

In the oral prose of the village of Nyuvchim the motif of blood relations with the tsar's family was recorded. In this respect, the image of the last Russian emperor Nicholas comes up. According to one of the adaptations, the manager Vassily Kosolapov (who was actually the manager while manufacturer and landowner Dmitry Bernadaki was the owner of the plant in 1880) was a secret son of the tsarist dynasty who brought his new-born son Sergey to Saint Petersburg to 'show him to his grandfather Emperor Nicholas and Empress Maria'40, while in other texts he was referred to as the 'emperor's servant', and the latter was referred to as the owner of the plant. In yet another source the emperor is referred to as 'a trustee' of the emerging industry, who was recruiting labour force, while his sister would bring them to these territories:

Emperor Nicholas gathered all of them together, the emperor from Saint Petersburg, he gathered all of them. The emperor's sister came over here and brought all of them. Well.... about two hundred people. Yes, he brought $236^{41}$ people here, Nicholas the emperor. ${ }^{42}$

The empress also took part in the development of the industry, and one of the texts tells about her intention to build a railway from the Pechora River to Nyuvchim:

Even Maria, the emperor's wife, ... wanted to build a railway from the Pechora River to Nyuvchim. Well, you see, when the White Army attacked, 
the war began. ... Valentin [informant's husband - Y.K.] would go hunting almost every Saturday and saw iron rail tracks, and on the rail tracks it was written: "Maria was here, Maria the empress." This is what was written on them. You see, they even wanted to build a railway from the Pechora River to Nyuvchim, for trains to travel here. She was Nicholas the emperor's wife. ${ }^{43}$

Another text was related to the image of the emperor-visionary and prophet:

[The emperor to Nyuvchim] Yes, he came here, he came indeed, but very long time ago. My mother told me that he did, without fanfare. The White Army was attacking. Without Maria. He wanted to see how Kosolapov was doing, he had hired him to manage this place. And he liked it, he liked everything here. They were sowing bread wheat, barley, groats, they did everything here. People were working because Kosolapov made them work. He would throw people out if they didn't work. [The emperor] praised Kosolapov a lot. But he warned us about what was coming, the year 1917. And in 1917, the revolution happened. It was such a mess in 1917. They turned everyone out, and we had been working so well here at the foundry. [The emperor] warned us not to work for them. ${ }^{44}$

In the narratives, Emperor Nicholas and representatives of the royal family are depicted as the founders and trustees of the industry, who express an interest not only in the development of the plant itself, but also its infrastructure (for example, the construction of the railway). The peculiar features of the characters (the motif of the secret arrival and staying in Nyuvchim, the ability to foretell the future, etc.) that are typical of the mythological image of a 'cultural hero' are highlighted in texts. ${ }^{45}$

\section{CONCLUSION}

The worldview paradigms of migrants, events related to reclaiming and inhabiting the territory, and information about local dynasties and historical figures, during the rule of which the plants operated and developed, were topics that were reflected in the historical prose of the Russian population living in mining and metallurgical settlements throughout the republic. It is worth mentioning that the structuring of collective historical memory in the twentieth century took place through the involvement of the mass media, book culture (on the part of local enthusiasts), local lore specialists, and the staff of local museums, schools, and libraries. This analysis of historical traditions allows us to record 
the process of active incorporation of information about historical events and famous historical figures of a Russian-wide scale into local chronicles, which served as a link between migrants and their Great Homeland, and enabled them to get involved in the Russian historical context, marking down the most significant landmarks of the local history.

\section{ACKNOWLEDGEMENTS}

This research was carried out within the research project No. 16-14-11001a(r), supported by the Russian Foundation for Basic Research and the government of the Komi Republic, and research project No AAAA-A17-117021310066-4.

\section{NOTES}

1 There are discrepancies pertaining to the dates of the commissioning of the Kazhym and Nyuchpas plants. In particular, Igor Zherebtsov writes that the plants had been in operation since 1759 (Zherebtsov 1994: 85, 167).

2 'Superimposed' elements can also be found in material culture: ethnographers do not rule out the influence of the types of dwellings typical of the areas that the newcomer plant workers came from, in particular, from the territories of Vyatka Governorate and 'especially Perm Governorate' (Zherebtsov 1962: 132-133); in terms of clothing, particular plant and urban characteristics were present; within the material culture of the village of Nyuvchim, the tradition of lace-making was preserved (making lace on bobbins), which was not typical for the local Komi culture but had a rich tradition in the nearby Vologda territories (Bandura \& Krasheninnikova 2011: 122) and others.

3 As a side note, in the Russian archives, rare recordings about the iron-ore industry in the Komi Republic have been discovered. For example, in the archive of the Russian Museum of Ethnography, there is material recorded by correspondent V. Pokrovsky in Koygorodsky municipality of Ust'-Sysolsky Uyezd in 1898, including at the Kazhym and Nyuchpas iron-ore plants (Archive of the Russian Museum of Ethnography. F. 7. Op. 1. D. 382, 370, 371), which contains very scarce and odd bits of information about plant settlements, production management, and the way of life of the local people (see Russian peasants 2008: 437-458). The documents from the pre-revolutionary period, mainly of statistical and production nature, are archived at the National Archive of the Komi Republic (funds 162-164). Individual items of information about the owners, the amounts of smelted ore and the number of plant workers as well as the channels selling the produce were discovered in documents in the Department of Manuscripts at the National Library of Russia (FXVII-111. L. 4-5). Information about the folklore culture of the local population was not recorded in the archives specified above.

${ }^{4}$ Field diaries are stored in the museum collections of the National Museum of the Komi Republic, and sound recordings are archived at the Folklore Fund of the Institute of Language, Literature, and History of the Komi Scientific Centre of the Ural Branch of the Russian Academy of Sciences. 
5 They have been partially published (see Krasheninnikova 2010).

6 It should be pointed out here that during the field research conducted in 2008-2017, only individual texts and fragments of song, game, and children's folklore as well as ritual and non-ritual lyrics were recorded, and within this context, the records made by Chistalyov are of extreme importance and value.

7 Many informants say that they learned some of the facts about the origins of settlements and plants, the range of product output, and the everyday life of plant workers and their years in the military from excursions and lectures organized by representatives of local museums and schools. The analysis of newspaper and magazine publications at the end of the nineteenth and in the twentieth centuries has demonstrated the stability of the following plots: the discovery of ore deposits and the birth of production, the social and economic status of plants in different time periods, the range of product output, and overviews of exhibitions, which also included information about the fact that the first settlers were peasants coming from different parts of Russia as well as about the owners and the relevance of the plants. Information about the participation of plants in the industrial life of the country, fulfilling special government and military orders, the so-called 'office casting' is also available.

8 The reference here is to the Demidovs' clan, not an individual member.

9 See Razumova (2001: 188-190) about these markers of family and biographical stories.

${ }^{10}$ Recorded by Y. Krasheninnikova in Nyuvchim, on 17 September 2008, from A.I. Silin, born in Nyuvchim in 1928. Every cited material is accompanied by a note containing information about the place and the year of the recording, the initials (name, patronymic name) and last name, and the year and place of birth of the respondent.

${ }^{11}$ Recorded by Y. Krasheninnikova in Nyuvchim, on 17 September 2008, from G.V. Silina, born in Yaroslavl Oblast in 1930.

${ }^{12}$ Recorded by Y. Krasheninnikova in Nyuvchim, on 17 September 2008, from E.P. Vorotnyova, born in Nyuvchim in 1927.

${ }^{13}$ Recorded by Y. Krasheninnikova in Nyuvchim, on 2 June 2015, from L.V. Semyachkov, born in Nyuvchim in 1944.

${ }^{14}$ Recorded by Y. Krasheninnikova in Kazhym, on 3 July 2010, from N.K. Usatova, born in Ust-Kulomsky District of the Komi Republic in 1938.

${ }^{15}$ Recorded by Y. Krasheninnikova in Kazhym, on 23 June 2013, from A.A. Burylova, born in the village of Bolshoy Kashnur in Kirov Oblast in 1933.

${ }^{16}$ Recorded by Y. Krasheninnikova in Nyuvchim, on 17 September 2008, from A.I. Silin, born in Nyuvchim in 1928.

${ }^{17}$ Recorded by Y. Krasheninnikova in Kazhym, on 3 July 2010, from P.I. Usatov, born in Kazhym in 1932.

${ }^{18}$ Recorded by Y. Krasheninnikova in Kazhym, on 6 July 2010, from A.A. Burylova, born in the village of Bolshoy Kashnur, Kirov Oblast, in 1933. 
${ }^{19}$ Recorded by Y. Krasheninnikova in Kazhym, on 2 July 2010, from L.V. Vavilova, born in Kazhym in 1930.

${ }^{20}$ Recorded by Y. Krasheninnikova in Kazhym, on 2 July 2010, from I.N. Kharina, born in Kazhym in 1923.

${ }^{21}$ Recorded by L. Lobanova and E. Fedoseyeva in Nyuvchim, on 18 November 2011, from P.A. Popov, born in Pevka in Syktyvdinsky District of the Komi Republic in 1929, and D.A. Popova, born in the village of Vizinga in Sysolsky District of the Komi Republic in 1931.

${ }^{22} \mathrm{~A}$ bonded peasant is a person that is bound under the feudal system, i.e., he or she does not have any civil or property rights (see Linguistic Dictionary).

${ }^{23}$ Recorded by Y. Krasheninnikova in Kazhym, on 24 June 2013, from E.A. Chistoprudova, born in Kazhym in 1936.

${ }^{24}$ Recorded by Y. Krasheninnikova in Nyuvchim, on 9 June 2015, from S.I. Vasilyev, born in Nyuvchim in 1937.

${ }^{25}$ Playing cards as a 'unique model of life', 'model of public life' (Lotman 1994: 136, 148) occupied the leading position among other games in the pastime of the Russian society in the eighteenth and nineteenth centuries (Komissarenko 2003).

${ }^{26}$ Recorded by Y. Krasheninnikova in Nyuvchim, on 4 June 2015, from L.P. Vasilishina, born in Nyuvchim in 1937.

${ }^{27}$ Recorded by Y. Krasheninnikova in Nyuvchim, on 17 September 2008, from A.I. Silin, born in Nyuvchim in 1928.

${ }^{28}$ Recorded by Y. Krasheninnikova in Nyuvchim, on 16 September 2008, from A.M. Sokolova, born in Nyuvchim in 1927.

${ }^{29}$ Recorded by Y. Krasheninnikova in Kazhym, on 3 July 2010, from V.N. Filyov, born in Kazhym in 1934, and from T.S. Filyova, born in Brest Oblast, Belorussia, in 1934.

${ }^{30}$ Recorded by Y. Krasheninnikova in Kazhym, on 5 July 2010, from V.A. Chegletsov, born in Kazhym in 1929, and from G.P. Chegletsova, born in Smolensk Oblast, Belorussia, in 1930.

${ }^{31}$ See Zelensky and Krasheninnikova and Bandura 2009 about artistic casting done at Nyuvchim iron foundry.

${ }^{32}$ Recorded by Y. Krasheninnikova in Kazhym, on 2 July 2010, from G.P. Lozitskaya, born in Kazhym in 1948.

${ }^{33}$ In Nyuvchim we were only able to record a single text related to the image of Demidov.

${ }^{34}$ Recorded by Y. Krasheninnikova in Kazhym, on 24 June 2013, from D.N. Shishnyov, born in Kazhym in 1932.

${ }^{35}$ Recorded by S. Nizovtseva and A. Rassykhayev in Nyuvchim, on 15 November 2011, from T.P. Raykhert, born in Nyuvchim in 1950. In the popular scientific paper "Ha далекой окраине. Как жили и боролись за свои права рабочие Коми края" (On 
the far-off outskirts: The way the workfolk on the territory of the Komi lived and fought for their rights), published in Syktyvkar in 1973, in an edition of 2,500 copies, we find the following: 'Metallurgical plants on the territory of the Komi had much in common with the Ural mining plants. They had this intrinsic "original formation" of the Uralian industry, which was described by V. I. Lenin...' (Surina 1973: 24).

${ }^{36}$ Recorded by Y. Krasheninnikova in Kazhym, on 3 July 2010, from P.I. Usatov, born in Kazhym in 1932.

${ }^{37}$ Recorded by S. Nizovtseva and P. Shakhmatskaya in Kazhym, on 22 June 2013, from G.A. Karavaeva, born in Kazhym in 1939.

${ }^{38}$ For example, in the essay "Кажимские горные заводы" (Mining Plants in Kazhym), when the history of their foundation is described, the image of a blacksmith from Tula named Demidov comes up: 'The desire to get rich fast was very tempting, and the laurels of a simple blacksmith from Tula named Demidov, who found fame, rank, honour, and wealth very fast, owing to his factories and plants, haunted the minds of the men of enterprise of the time' (Anisimov 1924: 59). In an essay about the Kazhym metallurgical plant, the 'rewarding experience of Demidov' is mentioned: '... the merchants from Ustyug (bearing in mind the rewarding experience of Demidov in the Urals) made a focused attempt at mineral exploration...' (Culture 2004: 62), and others. Obviously, the historical feature film "Demidovy" (The Demidovs), which was aired in 1983, should also be mentioned here. It has had a wide response, owing to which the image of Demidov could appear in local prose (I would like to thank V. Survo for this idea).

${ }^{39}$ By the way, in the historical prose of the Urals, it was the tsar Peter the Great who was attributed with such features, while Demidov appeared as 'an evil soul-taker' (Golovanov 2010: 131, 137-138).

${ }^{40}$ Recorded by Y. Krasheninnikova in Nyuvchim, on 17 September 2008, from E.P. Vorotnyova, born in Nyuvchim in 1927.

${ }^{41}$ It is a curious fact that the informant mentions a specific number that also came up, in particular, in newspaper publications and popular scientific reference books (e.g. Zherebtsov 1994: 166).

${ }^{42}$ Recorded by Y. Krasheninnikova in Nyuvchim, on 17 September 2008, from E.P. Vorotnyova, born in Nyuvchim in 1927.

${ }^{43}$ Recorded by Y. Krasheninnikova in Nyuvchim, on 17 September 2008, from E.P. Vorotnyova, born in Nyuvchim in 1927.

${ }^{44}$ Recorded by Y. Krasheninnikova in Nyuvchim, on 17 September 2008, from E.P. Vorotnyova, born in Nyuvchim in 1927.

45 The plot with the image of Emperor Nicholas deserves separate consideration, and I will only point out some individual aspects here. Almost all of the texts with the images of the representatives of the royal dynasty were recorded in 2008 from one informant who had been born and was living in Nyuvchim - a settlement located in the vicinity of Ust'Sysolsk (the current Syktyvkar). It would be tempting to assume that the appearance of Emperor Nicholas in the local prose could be influenced by information about the official visit to Ust'-Sysolsk of the Grand Duke Sergey Alexandrovich of Russia (who 
was the uncle of Emperor Nicholas, the last emperor of Russia), which took place on 3 June 1898 with the aim of becoming familiar with the military administrations of Vologda Governorate. The visit from the representative of the House of Romanov was described in detail in Vologda eparchial news bulletins. Leaving out the details of the visit, I will only mention that the programme of the stay included a visit to a local exhibition, which was set up outside of the building of Ust'-Sysolsk local government. At the exhibition, samples of graded wood meant to be exported abroad as well as forestry and timber industry products, samples of leathermaking industry, agricultural tools and crops, products of Nyuvchim metallurgical plant (author's emphasis - Y.K.) and the log sawing facility, Zyrian clothing, fishing and hunting tools, etc. were on display (VEV 1898: 608-609). According to my findings, this topic did not get a wide media coverage, because it was not popular enough; and the plot of a visit paid to Ust'-Sysolsk by the Grand Duke re-emerged and was debated significantly at the beginning of the twenty-first century.

\section{REFERENCES}

Anisimov, Aleksandr 1924. Kazhimskie gornye zavody (K materialam po istorii gornozavodskoi zhizni v Komi oblasti). [The Mountain Plants in Kazhim (To Materials on the History of Mining Life in the Komi Area).] Komi mu, No. 4-5, pp. 58-63; No. 7-10, pp. 40-44.

Bandura, Svetlana \& Krasheninnikova, Yulia 2011. Kul'turnoe nasledie Niuvchima: iz opyta prezentatsii muzeinoi kollektsii cherez fol'klornyi tekst. [Cultural Heritage of Nyuvchim: Experience of the Presentation of a Museum Collection through Folklore Text.] In: A. Kargin (ed.) Slavianskaia traditsionnaia kul'tura i sovremennyi mir. Vyp. 14: Kompleksnye issledovaniia traditsionnoi kul'tury $v$ postsovetskii period: sbornik nauchnykh statei. Moscow: Gosudarstvennyi respublikanskii tsentr russkogo fol'klora, pp. 121-130. Available at http://www. folkcentr.ru/slavyanskaya-tradicionnaya-kultura-i-sovremennyj-mir-vypusk14-kompleksnye-issledovaniya-tradicionnoj-kultury-v-postsovetskij-period/, last accessed on 2 July 2019.

Culture 2004 = Kazhimskii zhelezodelatel'nyi zavod (1755-1927 gg.). [Kazhim Ironworks Plant (1755-1927).] Kul'tura: izdanie Informatsionnogo tsentra kul'tury i iskusstva Respubliki Komi, No. 8, pp. 62-64.

Golovanov, Igor 2010. Mifologicheskie obrazy v fol'klornoi istoricheskoi proze Urala. [Mythological Images in Folkloristic Historical Prose of the Urals.] In: A. Kargin (ed.) Obraznyi mir traditsionnoi kul'tury: Sbornik statei. Moscow: Gosudarstvennyi respublikanskii tsentr russkogo fol'klora, pp. 129-140. Available at http://www.folkcentr.ru/obraznyj-mir-tradicionnoj-kultury-sbornik-statejm-gosudarstvennyj-respublikanskij-centr-russkogo-folklora-2010-352-s/, last accessed on 2 July 2019.

Komissarenko, Svetlana 2003. Igra v karty kak kul'turnaia traditsiia russkogo obshchestva XVIII-XIX vv. [Card Play as a Cultural Tradition of the Russian Society in the 18th-19th Centuries.] In: S. Komissarenko. Kul'turnye traditsii russkogo obshchestva. St. Petersburg: SPbGUP, pp. 88-106. Available at 
https://statehistory.ru/2266/Igra-v-karty-kak-kulturnaya-traditsiya-russkogoobshchestva-XVIII-XIX-vv-/, last accessed on 2 July 2019.

Krasheninnikova, Yulia 2010. Polevye dnevniki P.I. Chistaleva kak istochnik dlia izucheniia pesennoi fol'klornoi traditsii p. Niuvchim. [Field Diaries of P.I. Chistalyov as a Source for Studying Folk Song Tradition of the Village of Nyuvchim.] Muzei i kraevedenie. Trudy Natsional'nogo muzeia Respubliki Komi, Vyp. 7. Syktyvkar: Natsional'nyi Muzei RK, pp. 188-196.

Krasheninnikova, Yulia \& Nizovtseva, Svetlana 2019. Christmas in the Traditions of Russian Mining Settlements of the Komi Republic (as per Records of the Early Twenty-First Century). Folklore: Electronic Journal of Folklore, Vol. 76, pp. 119133. https://doi.org/10.7592/FEJF2019.76.krasheninnikova_nizovtseva.

Linguistic Dictionary = Lingvostranovedcheskii slovar'. [Linguistic and Cross-Cultural Dictionary.] Available at https://lingvostranovedcheskiy.academic.ru/260/, last accessed on 2 July 2019.

Lotman, Yuri 1994. Besedy o russkoi kul'ture. Byt i traditsii russkogo dvorianstva (XVIIInachalo XIX veka). [Conversations about Russian Culture: Everyday Life and Traditions of the Russian Nobility (18th - Beginning of the 19th Centuries).] St. Petersburg: Iskusstvo-SPb.

Politov, Valentin 2005. Promyshlennost' Komi kraia v XVIII v. [Industry of the Komi Region in the 18th Century.] Syktyvkar: Komi nauch. tsentr UrO RAN.

Razumova, Irina 2001. Potaennoe znanie sovremennoi russkoi sem'i: byt, fol'klor, istoriia. [Secret Knowledge of Modern Russian Family: Everyday Life, Folklore, History.] Moscow: Indrik.

Russian peasants 2008 = Russkie krest'iane. Zhizn'. Byt. Nravy. Materialy "Etnograficheskogo biuro" kniazia V. N. Tenisheva. [Russian Peasants: Life. Everyday Routine. Customs. Materials of the "Ethnographic Bureau" of the Duke V.N. Tenishev.] T. 5: Vologodskaia guberniia. Ch. 4: Totemskii, Ust'-Sysol'skii, Ustiugskii i Iarenskii uezdy. Compiled by T. Zimina \& O. Foniakova. St. Petersburg: Delovaia poligrafiia.

Surina, Lidia 1973. Na dalekoi okraine (Kak zhili i borolis' za svoi prava rabochie Komi kraia). [In the Far Periphery (How the Workers of the Komi Region Lived and Fought for Their Rights).] Syktyvkar: Komi knizhnoe izdatel'stvo.

Tolstoy, Nikita 1995. Iazyk i narodnaia kul'tura: Ocherki po slavianskoi mifologii $i$ etnolingvistike. [Language and National Culture: Essays about Slavic Mythology and Ethnolinguistics.] Moscow: Indrik. Available at http://e-heritage.ru/ras/view/ publication/general.html?id=46695533, last accessed on 2 July 2019.

VEV 1898 = Poseshchenie Ego Imperatorskim Vysochestvom Velikim Kniazem Sergeem Aleksandrovichem Vologodskoi gubernii (okonchanie). [Visit by His Imperial Highness the Grand Duke Sergey Aleksandrovich of the Vologda Province (End).] Vologodskie eparkhial'nye vedomosti: Pribavlenie, No. 24. 15 December, pp. 606-617. Available at http://pravoslavnoe-duhovenstvo.ru/media/priestdb/ materialattachment/attachment/99/59/9959f09a-61a5-4473-b8f3-8623d26714a5. pdf, last accessed on 2 July 2019.

Vlasov, Andrey 2007. Prostranstvenno-vremennye granitsy lokal'nykh/regional'nykh traditsii: Opyt opisaniia. [Spatial-Temporal Limits of Local/Regional Traditions: Experience of the Description.] In: M. Alekseevskii \& V. Dobrovol'skaia (comps.) Slavianskaia traditsionnaia kul'tura $i$ sovremennyi mir. Vyp. 10: Sbornik 
nauchnykh statei po materialam konferentsii. Moscow: Gosudarstvennyi respublikanskii tsentr russkogo fol'klora, pp. 7-22.

Ushakov, Dmitriy (ed.) 1939. Tolkovyi slovar' russkogo iazyka. [Explanatory Dictionary of the Russian Language.] Vol. 3. Moscow: Gosudarstvennoe izdatel'stvo inostrannykh i natsional'nykh slovarei.

Yefremova 2000 = Efremova, Tat'iana. Novyi slovar' russkogo iazyka. Tolkovoslovoobrazovatel'nyi. [New Dictionary of the Russian Language. Explanatory and Word-Forming.] Moscow: Russkii iazyk. Available at http://www.efremova. info, last accessed on 2 July 2019.

Zelensky \& Krasheninnikova \& Bandura (comps.) 2009 = Zelenskii, Vladimir \& Krasheninnikova, Iuliia \& Bandura, Svetlana. Khudozhestvennoe lit'e Niuvchimskogo chugunoliteinogo zavoda. [Ornamental Casting of the Nyuvchim Iron Foundry.] Seriia "Raritety". Vyp. 3. Set of postcards. Syktyvkar: Natsional'nyi muzei Respubliki Komi.

Zherebtsov, Igor 1994. Gde ty zhivesh': Naselennye punkty Respubliki Komi: Istorikodemograficheskii spravochnik. [Where You Live: Settlements of the Komi Republic: Historical and Demographic Reference Book.] Syktyvkar: Komi knizhnoe izdatel'stvo.

Zherebtsov, Liubomir 1962. K izucheniiu kul'tury i byta gornozavodskogo naseleniia Komi kraia (II polovina XIX - nachalo XX vv.). [To the Study of Culture and Everyday Life of the Mining Population of the Komi Region (the 2nd Half of the 19th - the Beginning of the 20th Centuries).] Istoriko-filologicheskii sbornik, Vyp. 7. Syktyvkar: Komi kn. izd-vo, pp. 121-138. 